\title{
Paradiplomacy in Creating Regional Competitiveness: Case Study of Jember Regency
}

\author{
Laode Muhamad Fathun \\ Universitas Pembangunan Nasional Veteran Jakarta
}

\begin{abstract}
Abstrak
Tulisan ini mendeskripsikan paradiplomasi pemerintah daerah Kabupaten Jember. Tulisan ini menunjukkan bahwa paradiplomasi pemerintah daerah Kabupaten Jember melalui diplomasi perkotaan dapat bertindak sebagai aktor yang bekerjasama dengan negara-negara seperti Jepang dan Kanada di pelbagai bidang untuk menjadi daerah yang aman dan nyaman. Untuk mengejar tujuan itu, pemerintah lokal berupaya mencari koneksi internasional melalui sister city dan smart city. Upaya ini merupakan strategi untuk memasuki era digital yang menuntut kawasan yang lebih inovatif dan kreatif. Kabupaten Jember menggunakan jenis paradiplomasi konservatif yang sejalan dengan Kementerian Luar Negeri sebagai koordinator hubungan luar negeri. Dengan demikian, hubungan dibangun dalam bentuk koordinasi yang harmonis antara pusat dan daerah. Di samping itu, kerjasama pendidikan juga dijalankan oleh Universitas Jember sebagai bentuk 'kekuatan lunak' untuk memperkenalkan kepada warga negara asing mengenai kesenian, nilai, dan budaya lokal.
\end{abstract}

Kata-kata kunci: paradiplomasi; Kabupaten Jember; jenis paradiplomasi konservatif

\begin{abstract}
This paper describes the paradiplomacy of the Jember Regency. This paper shows that the Jember Regency's paradiplomacy through city diplomacy can act as an actor who can cooperate with countries such as Japan and Canada in various fields in order to be a safe and comfortable regency. In doing so, the local government seeks to create international connections through sister cities and smart cities. This effort is a strategy to enter the digital era, which demands more innovative and creative regions. Jember Regency uses a conservative type of paradiplomacy which in line with the Ministry of Foreign Affairs as the foreign relations coordinator. Thus, the relationship built is in the form of a joint coordinator formula and parallel harmony between the capital city and the local government. In addition, educational cooperation was conducted by the University of Jember as a form of soft power to introduce many foreigners' artistic identity, values, and local culture.
\end{abstract}

Keywords: paradiplomacy; Jember Regency; conservative type of paradiplomacy 


\section{Introduction}

Every country in the world has national interests that must be achieved. The national interest is pursued by formulating foreign policy as a principal in the state's participation in international politics. Rosenau argued that foreign policy seeks to take advantage from external environment based upon the desired of maintaining the life of the country. Therefore, foreign policy analysis is very complex as it shall involve discussions regarding internal life and external needs (Rosenau, 1971). Foreign policy is inseparable from diplomacy. Every country will achieve its national interest through diplomacy. Diplomacy is a foreign policy instrument used to achieve these interests by peaceful means through government representation to other countries.

The changing course of foreign policy is determined by four factors; international order, threats and prevalence of war, revolution in the role of the state, and integration of information technology (Carlnaes, 2013). The direction of diplomacy may shift towards a new spectrum due to first, changes in the political, social, and economic environment in which diplomacy is carried out (e.g., the nature and distribution of power, new types of conflict, and the changing nature of sovereignty and interdependence in international relations), and second, because of the emergence of new international issues such as cybersecurity, privacy, data governance, e-commerce, and cybercrime, and lastly the use of digital tools in diplomatic practice such as social media, online conferencing, and extensive data analysis (Hone, 2021).

Changes in the practice of diplomacy are very significant and the actors involved are no longer exclusively composed by professionals working for the central government. Currently, local governments, both city and district governments, have already been and equally involved in foreign relations. From the dawn of the century, there has been indeed a major shift in foreign relations over which municipal and regional governments have been increasingly more relevant towards engagement in international policy discourse and processes (Curtis, 2014; Klaus, 2018). Inaccuracy however occurs when it has been quite customary to mark cities or districts becoming global political actors, and theorize them with urban diplomacy approach under the concept of "paradiplomacy." This is because the prefix "para" which means "parallel to", is misleading in today's context of international relations (Soldatos, 1990). The idea that city and regional actors operate in a diplomatic space parallel to the central government dominated by the nation-state, meaning that the action of the former ought to be seen as separate from that of the latter - has been a simplification of post-Westphalian reality (Van der Pluijm \& Mellisen, 2007). In reality, local and central governments operate in a diplomatic environment that does 
not distinguish between domestic and international exclusive territory. Under this concept, this simply means a rivalry between the center and the local regions in conducting foreign relations should not be practiced and disowned altogether.

The involvement of city or regency governments in international networks of global politics is increasingly massive. Although nationstates retain their power and resources to shape global agendas, cities are increasingly prominent on the world stage as powerful new actors (Acuto, 2013). Municipal diplomacy is an important tool of municipal governments to retain citizen support by advancing their global interests and attracting global investment and talent, increasing international visibility, and intervening in global flows of international relations (Lord, 2000). This urban diplomacy is both a cause and a consequence of the increasing importance of the urbanization process in international policy debates and processes. The new enthusiasm for jointly tackling common urban challenges and the availability of network channels should be seen as positive developments. The great potential of various types of city/regency networks and strategic alliances lies in their dynamic and innovative modes of operation. However, they also risk becoming increasingly competitive, especially regarding excessive territoriality (Rayner, 2016).

Why is city and local regency involvement important? UCLC states that there are two reasons as to why their involvement matters namely their difference in sizes and their variations of law. Other reasons would include a long-standing branding of city/regency, a global trend as a place of national, regional, and international coordination structures because of the growth of the city/regency increased by 200 percent, the city/regency consists of small cities of 50,000 inhabitants, intermediate cities between 100,000 people and big cities and mega-politicians or metropolises of 1 million people, and reconciliation and conflict resolution, global solidarity and development, strategic partnerships to deal with many threats and regional and international integration. (Grandi, 2020).

For example, municipal governments' involvement in international affairs is evident in September 2018 where mayors of twenty major cities gathered under the G20 and issued a joint communication calling national leaders to address the needs, demands, and imperatives of increasing global issues in cities. Capitalizing on their status as a center of population and economic activity, these twenty cities labeled themselves as the "Urban 20 " (U20) and are engaged in lobbying and advocacy aimed directly at the national leaders. They will soon assemble in Buenos Aires for the 2018 U20 meeting at the G20 annual Summit. A few weeks later, another, though less 
acclaimed, example of the city's involvement in world affairs occurred in Seoul, South Korea. Here, a group of city network representatives from unions such as Cities Alliance, Cities Climate Leadership Group (C40), ICLEI, and United Cities and Local Governments (UCLG) presented to IPCC members the Global Research and Action Agenda on World Cities and Climate Change (Amiri \& Sevin, 2020).

This city/regency diplomacy is both a cause and a consequence of the increasing importance of the urbanization process in international policy debates and processes. The new enthusiasm for jointly tackling common urban challenges and the availability of network channels should be seen as positive developments. The great potential of various types of city networks and strategic alliances lies in their dynamic and innovative modes of operation. However, they also risk becoming increasingly competitive, territorial, and redundant (Rayner, 2016). Moreover, even local interests with moral values have sometimes triggered cities and city networks into a "hostile position against the state," which is considered an "ineffective bureaucratic machine" (Acuto, 2013; 2016; 2017).

The role of city/regency diplomacy by paradiplomacy is also seen in Indonesia, where some cities have shown their foreign activities to achieve regional interests. This is inseparable from many constitutional and operational reasons and technical regulations that make the involvement of city/regency governments active in foreign relations. Several regulations such as Undang-Undang No. 37/1999 on foreign relations, Undang-Undang No. 24/2000 on international agreements, Undang-Undang No.23/2014 on regional government, Government Law /28/2018 on Regional Cooperation, Minister of Foreign Affairs Regulation No.3/2019, Minister of Domestic Regulation no. 25/2020 and some other technical regulations (Mukti, 2020). These rules become the essential reference for the Regional Government, the city, regency, or province. The involvement of the local government is then known as stretching paradiplomacy through city/regency or provincial diplomacy.

East Java Province covers the hinterland region, consisting of Jember Regency, Bondowoso District, and Situbondo District. Jember Regency is bordered by Bondowoso and Probolinggo Regencies in the north, Lumajang District in the west, Banyuwangi District in the east, and the south by the south Indonesian ocean. Jember is one of the districts in East Java Province. Jember Regency is located on the Yang Mountains and Mount Argopuro, stretching southward to the Indonesian Ocean. In the regional context, Jember Regency has a strategic position and role as one of the Regional Activity Centers (Pemkab Jember, 2019). 
The existence of Jember Regency geographically has a very strategic position with various potential natural resources and many historical events. Jember Regency consists of 31 sub-districts with a total of 248 villages. The total area of Jember Regency is 3,293.34 $\mathrm{km}^{2}$ or $329,334 \mathrm{Ha}$, which is located in the coordinate position of $6^{\circ} 27^{\prime} 6^{\prime \prime}$ to $7^{\circ} 14^{\prime} 33^{\prime \prime}$ East Longitude and 7059' $6^{\prime \prime}$ to 8033'56" South Latitude. Therefore, if we look at the area, the most expansive area in Jember Regency is Tempurejo District, with 524.46 $\mathrm{km}^{2}$. The narrowest is Kaliwates District with an area of $24.94 \mathrm{~km}^{2}$ (Pemkab Jember, 2019).

Along with the development of the times, there were several changes in these regulations, such as changes related to the Jember District Government which was initially divided into 7 District Areas on 1 January 1929 since the enactment of Staatsblad Number 46 of 1941 dated 1 March 1941 The District Area was divided into 25 Onderdistrik, namely: District of Jember, covering the districts of Jember, Wirolegi, and Arjasa; Kalisat District, covering the onder-districts of Kalisat, Ledokombo, Sumberjambe and Sukowono; Rambi Puji District, which includes Rambi Puji, Panti, Mangli, and Jenggawah districts; Mayang District, covering the districts of Mayang, Silo, Mumbulsari and Tempurejo; Tanggul District, covering Tanggul, Sumberbaru and Bangsalsari districts on; Puger District, covering the districts of Puger, Kencong, Gumukmas and Umbulsari; Wuluhan District, covering Wuluhan, Ambulu and Balung . districts (Pemkab Jember, 2019).

Jember Regency is one of the autonomous regions in Indonesia that may have the potentials to carry out and craft their trajectory of foreign relations. As a paradiplomacy actor who conducts foreign relations through urban diplomacy, this can be an opportunity and a challenge for the Regional Government to innovate their regions as a branding identity that can get the economic potential of these foreign relations. However, the involvement of the Regional Government as a Paradiplomacy that carries out urban diplomacy in Indonesia has not been optimal. This is based on several good reasons the constitution that international affairs are a central responsibility. However, regional orientation is not yet outward-looking. Another problem is the availability of human resources that are not good and the availability of institutional divisions that regulate or manage foreign relations.

This article has contributed to the study of paradiplomacy in Indonesia. This field of study has come to prominence due to the operational and technical regulations that have facilitated and made the regional involvement in foreign relations possible. Thus, this article helps to explore the role of the Regency of Jember's paradiplomacy in achieving regional interests abroad. The contribution of this article will be beneficial 
for conceptualizing and ingraining the concept of paradiplomacy to the foreign activities of regional districts, which later serves as bridge between the theoretical - academic approach and the practical world.

\section{Paradiplomacy: A Conceptual Framework}

In theory and practice, paradiplomacy in Indonesia is not always the same as in other countries, according to the types and formulas used by paradiplomacy in foreign relations. This depends on the $3 \mathrm{C}$ design or concept regarding the regional vision of whether to make foreign relations one of its policies. In addition, there is competence concerning the readiness of human resources as actors who can implement policies both in terms of substance and technical aspects. Furthermore, connectivity concerns the readiness of partners and technology to connect cooperation between actors so that this design will make it easier for this paradiplomacy to stretch foreign relations (Kartajaya, 2005).

In addition, what needs to be considered and is still a debate in Indonesia's theory and practice of paradiplomacy is the difference in nomenclature between districts, cities, and provinces. Each of the three actors can conduct foreign relations based on the orientation and policies of each region. According to (Tavares, 2016), public policies of sub-national governments which generally have foreign components include: (1) trade and investment; 2) environment and sustainable development; (3) tourism, culture, and sports; (4) social policy; (5) economic development, industry, infrastructure, and agriculture; (6) communication and branding; (7) credit and loans; (8) international development assistance; (9) lobbying; or (10) major events. Therefore, the subnational level is very important to understand the dynamics of global FDI. A transverse view of initiatives undertaken at the subnational level suggests that any investment promotion strategy should be directed at the following: (1) image-building activities that promote the country and its territory and declare it a favorable location for investment; (2) activities that generate investment through direct targeting of companies with the promotion of specific sectors and industries, and personal selling and establishing direct contact with potential investors; (3) investment service activities tailored to the needs of potential and current investors; and (4) activities that increase the realization ratio (for example, the percentage of FDI approvals translated into actual flows) (Tavares, 2016). 
Table 1. Models of Paradiplomacy

\begin{tabular}{|l|l|l|l|l|}
\hline No & Type/Indicator & \multicolumn{1}{c|}{ Isolative } & \multicolumn{1}{c|}{ Conservative } & \multicolumn{1}{c|}{ Progressive } \\
\hline 1 & Foreign Policy & is at the centrallevel & is at the central level & is at the centrallevel \\
\hline 2 & Diplomatic role & $\begin{array}{l}\text { There is no authority } \\
\text { on foreign cooperation } \\
\text { initiatives but } \\
\text { assignments from the } \\
\text { center }\end{array}$ & $\begin{array}{l}\text { There are overseas } \\
\text { cooperation initiatives } \\
\text { but controlled by the } \\
\text { center }\end{array}$ & $\begin{array}{l}\text { There is an authority for } \\
\text { foreign cooperation } \\
\text { initiatives that can be } \\
\text { carried out by } \\
\text { paradiplomacy }\end{array}$ \\
\hline 3 & $\begin{array}{l}\text { Overseas } \\
\text { representative } \\
\text { office }\end{array}$ & $\begin{array}{l}\text { Only available at the } \\
\text { central government } \\
\text { representative office }\end{array}$ & $\begin{array}{l}\text { Only available at the } \\
\text { central government } \\
\text { representative office }\end{array}$ & $\begin{array}{l}\text { Local governments with } \\
\text { specific criteria may } \\
\text { open representative } \\
\text { offices }\end{array}$ \\
\hline 4 & $\begin{array}{l}\text { Preparation of } \\
\text { cooperation } \\
\text { documents with } \\
\text { foreign parties }\end{array}$ & $\begin{array}{l}\text { Through the mandate } \\
\text { of the center of Full } \\
\text { power }\end{array}$ & $\begin{array}{l}\text { Through the mandate } \\
\text { of the center of Full } \\
\text { power }\end{array}$ & $\begin{array}{l}\text { No mandate, but } \\
\text { coordination }\end{array}$ \\
\hline
\end{tabular}

Source: Mukti, 2020.

The stretch of paradiplomacy through urban diplomacy in foreign relations is significant. An urban diplomacy is a form of diplomacy that aims to bring the interests of the city (region) at the international or regional level in line with the state's interests. Of course, this city diplomacy aims to become an influential global city in many countries. Therefore, many experts conclude that city diplomacy refers to the role of city governments in the development of foreign relations. City diplomacy is a form of diplomacy that aims to bring the city's interests (region) at the international or regional level in line with the state's interests.

Municipal diplomacy activities can be divided into two groups: (1) self-funded activities, allowing the highest degree of discretion. The maximum amount of money available for municipal diplomacy is usually determined by national laws and local budgets. 2) Activities are financed by external actors, such as international organizations, development banks, government ministries and agencies, embassies, consulates, cultural institutions abroad, NGOs, and the business world. Two initial steps of the partnership must be implemented: (1) Dialogue, if possible in the context of an exploratory visit, to ensure the commitment of both parties and agree on the rationale of the partnership (2) operational, strategic plan implementation. City diplomacy is carried out through city partnerships through institutional visits and reciprocal training, direct relations between cities, and the exchange of delegates by the community (Grandi, 2020).

City brands consist of two dimensions: representational and functional. The representational dimension rests on consumers' use of brands to help express themselves (Caldwell \& Freire 2004:52). For 
example, the choice of vacation destinations is also used by consumers to differentiate them and to communicate messages about themselves to their peers (Caldwell \& Freire 2004:52). This is especially true in the age of social media when tourists take selfies and share their holiday experiences on social media. Thus, the representational dimension of a city's brand rests on the values, emotions, and beliefs that cities evoke and how people choose to represent their experiences in them. The functional dimension rests on the idea that consumers choose brands that help them meet specific needs. Therefore, the functional dimension of the city brand includes the city's physical attributes, such as museums, beaches, mountains, festivals, etc. Finally, city branding often focuses on culture and the arts (Kavaratzis 2009; Amiri \& Sevin, 2020).

\section{Economic Potential of Jember Regency}

The development of the economy was so rapid, resulting in the emergence of new trading centers, especially trade in agricultural products, such as rice, secondary crops, and others, the centers of government at the district level-shifted, such as the Wuluhan district to Balung. In contrast, the Puger district shifted to Kencong. Law Number 12 of 1950 concerning Regency Regional Government in East Java stipulates the formation of Regency Areas within the East Java Province (with a Regional Regulation), including the Jember Regency Area designated as Jember Regency (Pemkab Jember, 2021). However, with the enactment of Regional Autonomy as demanded by Law Number 22 of 1999 concerning Regional Government, since 1 January 2001, the Jember Regency Government has also made institutional arrangements and organizational structures, including the abolition of the Jember Administrative City. Likewise, the Assistant District Head was changed to the Camat Coordination Office. However, after evaluating Otonomi Daerah one year after its implementation, the Jember Regency Government, through Regional Regulation Number 12 of 2001, liquidated the Camat Coordination Office (Pemkab Jember, 2021).

In the era of Regional Autonomy, the Jember Regency Government has managed to organize organizational and institutional structures up to the village and kelurahan levels. However, starting from 1 January 2001, Jember Regency enters a new paradigm in the government system, namely from a centralized system to a decentralized system or Regional Autonomy, by implementing ten mandatory autonomy authorities that provide full freedom to regulate and manage their domestic governance in accordance with the wishes and aspirations of its people and with the applicable laws and regulations. This approach has been the main mission designated to achieve several objectives namely among others, improving the welfare of the community (Pemkab Jember, 2021). 
The topography of Jember Regency tends to be hilly. In the north and east, there is a fertile plain area that extends to the south. The mountainous natural condition also borders the ocean (Indonesian Ocean), which is the advantage of the Jember Regency area, especially in the agricultural and tourism sectors. Generally, the sub-districts in Jember Regency have a relatively flat expanse or a slope between $0^{\circ}$ to $2^{\circ}$, including the Districts of Wuluhan, Ambulu, Gumuk Mas, Umbulsari, Ajung, Jombang, and Kencong. Meanwhile, about $70 \%$ of the area is mountainous with a land slope of more than $40^{\circ}$, namely the Districts of Silo, Panti, Tanggul, and Tempurejo. The area of Jember Regency is located between an altitude of zero degrees to more than a thousand meters above sea level. The altitude above sea level is one of the factors that determine the type of population activity. The height of the place can be used as one of the determinants of the business area boundaries (Rochman, 2015).

Based on the geographical condition of Jember Regency, a promising economic business for the community is agriculture. Population data shows that the agricultural business field absorbs the most labor compared to other business fields in Jember Regency. The agricultural sector can absorb 46.90 percent of all job seekers, or in other words, the agricultural sector in Jember Regency is a priority sector. Leading sector that need attention from the local government in the context of regional economic development. The agricultural sector provides a fairly significant contribution to the GRDP of Jember Regency. It has increased every year with a value of 4,619.63 billion rupiahs in 2009 and increased to 5,205.90 billion rupiahs in 2013. The second sector that contributed significantly to the GRDP of Jember Regency is the trade, hotel, and restaurant sectors. The value of this sector was 2,698.52 billion rupiahs in 2009 and increased to 3,701.08 billion rupiahs in 2013 (Rochman, 2015).

One of the potential economic resources of Jember Regency is the tourism sector. Based on data from the Badan Pusat Statistik Jember Regency, promising fields to be developed as a Jember Tourism Potential should include Nature Tourism such as Bukit Watu Pecah Ambulu Nature Tourism, Watu Ondo Area Nature Tourism, Tancak Waterfall Nature Tourism, Seputih Waterfall Nature Tourism, Saroyo Hill Nature Tourism, Rowosar Waterfall Nature Tourism, Puncak Payangan Nature Tourism, Papuma Beach Nature Tourism, Nanggelan Nature Tourism Meru Betiri National Park, Getem Muara Mangrove Nature Tour, Kaliklepuh Waterfall Nature Tourism, Sunrise Nature Tourism Gumukmas Village, East Estuary Nature Tourism Bande Alit Beach, Anugrah Waterfall Nature Tourism, and Domba Hill Nature Tourism. There are still many other natural tourist attractions in Jember that the district government continues to develop so that this potential can generate economic income in the tourism sector (BPS Kabupaten Jember, 2021). 
In addition, there are Artificial Tours such as Niagara Water Park, Mumbul Garden, Jember Fashion Carnaval, Glantangan Golf, Sukorambi Botanical Garden, Alun-Alun, Tiara Jember Park, Miniature Jember in the Jubung Rest Area, Kimo Baths, Glantangan Agro Tourism. Jember Cultural Tourism offers a cultural tourism experience by displaying the uniqueness of the region. The following among the cultural tourism of Jember Regency are: Tota'an Merpati, is a typical tradition in Semboro sub-district, Jember Regency which represents a tradition called Tota with its trademark, namely the dove as a symbol of peace and harmony. Currently, there are 23 reog groups in Jember, which among others are scattered in the southern Jember region, such as Kalisanen, Sidodadi, Pontang, Ambulu, Wuluhan, to Kencong District. They manage this group with self-reliance and independence. Kerapan Sapi is a traditional cow racing event that children usually follow. This race is an exciting and rare event enjoyed by tourists. Furthermore, there are also Historical Tourism. Jember also has many relics from prehistoric times that attract tourists, such as Dolmen at the Srino Sukowono Site, Sarkopagus at the Seputih Mayang Site, Yoni Pucangsari at the Pucangsari Sukowono Site, Archaeologists at the Pakel Jelbuk Site, and various archaeological sites many others are found in Jember Regency (BPS Kabupaten Jember, 2021).

\section{Jember Regency's Paradiplomacy}

In terms of tasks and functions, the activities of paradiplomacy in Indonesia could have both similarities and differences from the provincial government. The Provincial Government oversees both the City OR Regency Governments. Cities and districts usually differ in terms of progress and mobility. In theory and practice, paradiplomacy in Indonesia is not always the same as in other countries, according to the types and formulas used by paradiplomacy in foreign relations. This depends on the $3 \mathrm{C}$ design or concept regarding the regional vision of making foreign relations one of its policies. In addition, there is competence concerning the readiness of human resources as actors who can implement policies both in terms of substance and technical aspects. Moreover, connectivity concerns the readiness of partners and technology to connect cooperation between actors so that this design will make it easier for this paradiplomacy to stretch foreign relations (Kartajaya, 2005).

In addition, what needs to be considered and is still a debate in Indonesia's theory and practice of paradiplomacy is the difference in nomenclature between districts, cities, and provinces. Each of the three actors can conduct foreign relations based on the orientation and policies of each region. According to (Tavares, 2016), public policies of sub-national governments which generally have foreign components include: (1) trade 
and investment; 2) environment and sustainable development; (3) tourism, culture, and sports; (4) social policy; (5) economic development, industry, infrastructure, and agriculture; (6) communication and branding; (7) credit and loans; (8) international development assistance; (9) lobbying; or (10) significant events. Therefore, the subnational level is essential to understand the dynamics of global FDI. A transverse view of initiatives undertaken at the subnational level suggests that any investment promotion strategy should be directed at the following: (1) image-building activities that promote the country and its territory and declare it a favorable location for investment; (2) activities that generate investment through direct targeting of companies with the promotion of specific sectors and industries, and personal selling and establishing direct contact with potential investors; (3) investment service activities tailored to the needs of potential and current investors; and (4) activities that increase the realization ratio, for example, the percentage of FDI approvals translated into actual flows (Tavares, 2016). For example, although Makassar is an autonomous region, Makassar is also the capital of Southeast Sulawesi Province. Likewise, the city of Surabaya is its autonomous region, but Surabaya is also the representation and capital of the province of East Java. Another example, Kendari City became its autonomous region and became the capital of Southeast Sulawesi Province. This difference has consequences on the theory and practice used between using paradiplomacy or city diplomacy. In this context, although the nomenclature is different, the tasks and functions remain the same to have opportunities in foreign cooperation. This means that the difference between a City and a District is not seen from the name but the action. A district can be called a district, while a city is called a city and a province is called a region.

When talking about global cities/regencies, there are two things: city as a place where the city must be a safe, comfortable place and a metropolis to live in, a place to do business, and a community place. In addition, a city as actors is defined as a city that can map its potential to be competitive and create branding so that it is known so that it can contribute to local development. National and international. Why is the involvement of cities important in foreign relations? It is most likely because globalization makes interactions becoming more complex. As a result, Acuto called it an international bias. This situation will bring the phenomenon of urbanization of people moving from villages to cities because the city promises prosperity, a new culture, a new community. Then the phenomenon of displacement will create a Relationship. This relationship will determine the area involved in various situations (Acuto, 2013). In the involvement of paradiplomacy as actors, they cooperate in various fields according to their needs. 


\section{Intergovernmental Cooperation}

Paradiplomacy carried out by Jember regency acts as an actor in foreign relations, namely the collaboration between Jember Regency and Canada. The Jember Regency Government has launched a collaboration with the Canadian government. In the meeting between the two, the Jember Regency government was represented directly by the Regent of Jember, while the Canadian government was represented by the Canadian Embassy in Indonesia (Pemkab Jember, 2019). The embassy officials who met with the Regent were Geofrey Dean (Political Counselor) and Colin Wetmore (First Secretary). The meeting discussed various programs that could be collaborated between the Jember Regency Government and the Canadian government. Among the proposed programs, the Regent of Jember expects investment from Canada.

According to the Jember Regency, the Canadian embassy has noted the hopes and priorities of the Jember Regency Government, one of which is related to support for the arrangement of the city master plan. The Regent of Jember hopes for this collaboration because Canada is a modern city with mass transportation and good waste management (Pemkab Jember, 2019). The meeting also discussed tourism and education. In education, it is possible to have programs that allow students in Jember to study in Canada before going to college. The program is planned to last around two weeks to one month. In addition, this program hopes that many students will have the opportunity to study abroad (Pemkab Jember, 2019). According to the Dutch-American sociologist Saskia Sassen, global cities have four characteristics: "first, as highly concentrated points of command within the organization of the world economy; second, as a prime location for finance and for specialized services firms, which have replaced manufacturing as the main economic sector; third, as a place of production, including the production of innovation, in this leading industry; and fourth, as a market for products and the resulting economic innovations." Furthermore, Sassen argues that the emergence of communities and networks of cities makes political formation a new place. (Sassen, 2013; 2017).

The Jember Regency Government has established mutually beneficial cooperation with Japan through the Japanese Consulate in Surabaya. The negotiations began with a meeting between Regent of Jember and the Japanese Consulate group led by Tani Masaki, at Pendapa Wahyawibhawagraha on Tuesday 19 March 2019. This collaboration between Jember and Japan covers the MSME, tourism, and education sectors. In addition, this collaboration includes plans for training MSMEs and studying in Japan, exchanging tourist destinations, and groups of study and tourism visitors (Wahyunik, 2019). City/regency diplomacy is essential because it makes the region a global actor to bring the region's interests and society at the global level 
such as economy, migration to the region, or becoming a conflict mediator. It also takes a role as a community representation at the international level who voices events in the region. City diplomats will present problems in their regions as a form of commitment to become representatives. It also creates joint solidarity, namely a form of association where efforts to protect all forms owned by the city from disturbance (Acuto, 2013). There are six dimensions of the role of city diplomacy, namely security, development, economy, representation, networking, culture (Melissen, 2007).

\section{International Cooperation in Education}

Although this activity does not directly focus on the involvement of the Jember Head District Government, the main target is to create superior and reliable human resources for future generations. University collaboration by collaborating with some other universities is a concrete form of this target. This means that the University of Jember can enrich education quality, which produces quality and competitive Jember citizens. The keyword is that the success of an area must be supported by good quality higher education. Because Higher Education will produce graduates who can help develop the region. It has become commonplace that the success of an area in building civilization is due to the existence of quality higher education in the vicinity, such as the Jember Head District Government, which has the University of Jember. The following are several foreign collaborations from the University of Jember to improve the quality of human resources.

One of the universities in Jember Regency, namely the University of Jember, has collaborated with foreign universities to support the quality of human resources with programs, one of which is to support the exchange of lecturers and students to attend lectures and conduct research related to their respective fields. Each is in a foreign university that has supporting facilities. Universities that have been registered and actively cooperate with the University of Jember consist of Asian universities such as the Prefectural University of Hiroshima (PUH) in Japan, Kyungpook National University (KNU) in South Korea, University Malaysia Terengganu in Malaysia, and Kasetsart University in Thailand. The University of Jember targets this collaboration to take place in the long term and, in the future, hopes to open collaborations with universities in the European Union (Universitas Jember, 2020).

The UJICC (Universitas Jember International Cultural Camp) program is a program created with the aim of introducing culture and the environment such as language, art, local wisdom and natural beauty in 
Jember to partner universities abroad. This program is an effort from the University of Jember to create a world-class University. The implementation of the UJICC program is coordinated by the Office of International Affairs and several representatives from the University of Jember (Berita Ekspres, 2016). The UJICC program provides opportunities for international students not only to learn and get to know the University of Jember but also to see and learn about the culture in Jember, local wisdom, ecology, agriculture, and leading industry in Jember Regency.

Jember Regency is already one step ahead of many other Head District Governments in Indonesia that do not yet have an outward-looking orientation or vision. According to the theoretical analysis above, the second role of urban diplomacy carried out by para-diplomacy is place. The author identifies two essential things that paradiplomacy can do (the Jember Regency Government in urban diplomacy): sister cities and smart cities. Of course, as an autonomous region, the Jember Regency Government must ensure that the regency is a safe, comfortable place for creation, investment and mobilization, and recreation. The above has shown several potentials owned by the Jember Regency Government that can attract investment in the region.

The educational collaboration carried out by the University of Jember can be an effort to introduce the identity and culture of Jember to international students. This means that urban diplomacy is a new soft power to attract global cultural, social, and economic capital and form better opinions about the foreign policy objectives of local constituents. Nye (2004) initially defined soft power as the ability of a country to influence others. Through persuasion, ideas, and cultural appeal. Urban soft power can be appreciated through the same lens as the power to have global influence based on local reputation through cultural exchange, advocacy, and policy collaboration (Amiri \& Sevin, 2020). Local governments take advantage of their urban appeal, international image or brand in a global context, and other resources such as economy and technology. This noncoercive source of power, based on urban culture, values, and economic assets. The Cooperation activity is an essential agent of cultural diplomacy, which is defined as "the cross-cultural exchange of ideas, information, arts, and cultural aspects among nations and their societies to promote mutual understanding" (Cummings, 2003).

Jember Regency Government in carrying out a sister city can be reached with two events, namely intra-government and extra-government. Intra-government can be done through domestic cooperation as a support for the domestic economy. This means establishing inter-regional cooperation in the territory of one province or outside the province but still within the territory of Indonesia. This can be achieved by forming a regional cooperation 
triangle such as Jogya-Jember Surabaya or Jogya-Jember-Bandung. Why are these three cities important? Because if we look at the economic potential, tourism potential and the quality of education in the three cities are very good. For example, they took the Jogyakarta Province tourism sector for the last two years, 2020 and 2021. Data from the Jogya Provincial Government shows that Nusantara tourists visiting Jogya in 2020 and 2021 reached 1,778,580 people and 69,958 foreign tourists. In Yogyakarta Province, there are the best universities in Indonesia and the best universities in the Asian and regional world levels, namely Gajah Mada University. In addition, it is also supported by several other universities that also have quality. UGM is in position 254 for the ranking of world universities according to the QS World University Ranking.

For Surabaya based on investment data in 2020 it will reach 1,507,080,597,587 Rupiah and 99,497,963, 753 Rupiah (Surabaya, 2021). For the education sector in Surabaya, Airlangga University is also of the best quality in Indonesia. Furthermore, it occupies the 521-530 version of the QS World University Ranking. Likewise with Bandung shows the development of investment and education in 2020-2021. According to BKPM data in 2020, West Java Province contributed 112.7 trillion for domestic investment and 97.6 trillion for foreign investment. Meanwhile, for 2021, the West Java Provincial Government will become a Regional Government that ranks first in domestic investment, namely 198 trillion and foreign investment of 111.7 trillion (Bisnis, 2021). In addition, in the field of Education, Bandung also has the best universities at the national level. Also, it has the best ranking at the international level, namely the Bandung Institute of Technology, which is in position 313, and Padjadjaran University in rank 801-1000 according to QS World Ranking 2021. This fact is proof that it is essential to become a strategic partner in the Triangle of Cooperation between Jember, Yogyakarta, Surabaya, and Bandung.

Another opportunity is that this intra-government sister city collaboration can be widened in the context of the branding identity of each city as a tourism area-for example, Jogya by Branding the city of arts and culture and education. Then the city of Bandung with the branding of Paris Van Java and Surabaya as the City of Heroes and Jember as the City of World Fashion Carnaval. In addition, the Jember Regency Government promotes several local products such as chocolate, batik, etc. This collaboration is crucial for advancing cities in a domestic context. In addition to building coordination and collaboration with several City Governments and Provincial Governments in various regions, the Jember Regency Government must also build Sister City Cooperation with several other countries. This can be developed from international cooperation carried out by the Regency Governments. For example, with the Canadian 
government. This collaboration with the Canadian government can be developed in various fields, especially in tourism and education.

The Jember Regency Government provides several quality tourist destinations that can be used as places of recreation for both culture, art, and local products for Canadian residents. In addition, Canada itself can provide scholarship exchanges for Jember residents in education to ensure the quality of human resources. In Canada, there are several strategic colleges such as the University of Toronto, which is in the $25^{\text {th }}$ global ranking, McGill University, which is in the $31^{\text {st }}$ position in the global ranking and British Columbia University, which is in the $45^{\text {th }}$ position in the global ranking, and several other universities which are also in the $100^{\text {th }}$ position (IDP, 2021). Therefore, it will significantly improve the quality of education in Jember. Moreover, the mechanism can be done through sister university collaboration with the University of Jember. Urban soft power refers to the global community's brand, attractiveness, and reputation that cities build. Cities use this power (Van der Pluijm \& Mellisen, 2007) to influence the global agenda in important policies to their citizens' prosperity, security, and well-being. This strength lies in the representative dimension of city diplomacy, or in other words, city branding. City imagery usually refers to the strategic efforts of various stakeholders to market a city "to attract investment, customers for its export products, or visitors for its tourism industry" (Deganutti, 2017).

The Jember Regency Government also conducts foreign cooperation with the Japanese government. This is also a good opportunity for the District Government because Japan is an excellent country in education, technology, and management of economic resources such as MSMEs. In the field of education, of course, the sister university mechanism can conduct student exchanges with a number of the best universities such as Kyoto University, Nagoya University, Tokyo University, and several other universities in Japan. In addition, of course, to build good human resources, quality technology, and management of economic subarrays, Japan is a country that can provide knowledge sharing through student exchanges between universities facilitated by the Jember Regency Government and Jember University.

The movement of the Jember Regency Government as a paradiplomacy actor who carries out city/regency diplomacy must also be equipped with regional readiness to integrate information technology. This concrete form is an effort to welcome regional involvement in foreign relations in the digital era. The concrete form of this activity is through intelligent cities. Why smart city, because smart city opens up opportunities for investors to invest in Jember Regency. Collaboration with Canada and Japan can also positively impact the opportunity to create a smart city. Jember Regency 
received an award as one of the cities that implemented an smart city in the intelligent branding category. The Head of Jember Regency policies, such as Perda No. 9/2016 regarding the Protection of People's Markets and Supermarket Arrangement, Regional Regulation No. /2/2018 concerning the empowerment of local workers, Perda No. 9/2016 which requires supermarkets to empower at least 20 percent of local products. This positive step reduced the poverty rate in Jember Regency from 5.16 percent to 4.09 percent in 2017. which prioritizes local products and local work is a progressive step to take advantage of regional assets. The $4 \mathrm{C}$ theme, namely Coffee, Chocolate, Cigar, and Culture, is a concrete step to create a smart city and intelligent branding (Jemberkab, 2021).

Regarding the smart city, Telkom Indonesia's design can be a reference for the Jember Regency Government to see the quality of the Jember smart city. There are nine categories of intelligent cities: Smart Energy, namely the fulfillment of an efficient storage system and use of energy sources; Smart Building, namely the application of intelligent, energy-efficient (green building), automation systems and using Advance HVAC (Heating Ventilation \& Air Conditioning); Smart Mobility, namely the use of sophisticated traffic management systems, parking management and multi-mode transportation modes; Smart Technology, namely the realization of seamless connectivity including $4 \mathrm{G}$, Wi-fi, superbroadband, 1 GB/s download, Augmented Reality, LBS, and GPS; Smart Infrastructure, namely the use of integrated sensor management; Smart Governance \& Education, namely the establishment of e-Government, e-Education and disaster management solutions; intelligent health care, namely the availability of e-Health, $\mathrm{m}-\mathrm{Health}$ and innovative and interconnected media equipment; Smart Citizen, namely the emergence of awareness to carry out new habits or cultures that are closely related to the Go Green-based transportation system to live a healthy lifestyle; and Smart Security, namely the creation of surveillance guarantees, biometrics, prevention models for various crimes and disaster anticipation (Fathun, 2016; 2018). Furthermore, Madani (in Fathun, 2018) states that there are six indicators, namely Smart Governance (transparent, informative, and responsive government), Smart Economy (growing productivity with entrepreneurship and the spirit of innovation), Smart People (improvement of Human Resources and decent living facilities), Smart Mobility (providing transportation system and infrastructure), Smart Environment (management of natural resources that are environmentally friendly), and Smart Living (realizing a healthy and livable city).

Thus, Jember Regency can coordinate with the West Java Provincial Government and the Surabaya City Government to implement this smart city because these two cities are row models of Indonesia's smart city. 
Thus, successful city branding requires one to view the city as a holistic brand consisting of many products, including urban landscapes, culture, architecture, design, and urban infrastructure. Mega-events can play an important role in city branding as they attract prolonged media attention and can lead to infrastructure and architectural changes that create new landscapes for the city (Amiri \& Sevin, 2020).

This opportunity could be a moment for Jember Regency to design a more integrated Jember Regency with information technology. In this context, Japan can create branding that the public can know. This means that the soft power emanates from its culture, social values, domestic institutions, and foreign policies. Therefore, national branding is a tool for soft power projection. Branding campaigns aim to improve the image of a nation by telling stories about the norms that shape domestic politics, the values that determine its foreign policy, and its arts, history, and culture (Nye, 2004; Amiri \& Sevin, 2020).

Cities have refined their practice of addressing transnational issues such as climate change, urbanization, mobility, migration, violent extremism, and, more recently, the COVID-19 pandemic by building horizontal partnerships with their peers worldwide and encouraging them through vertical partnerships with their residents and local stakeholders. Thanks to such an approach, urban diplomacy has evolved into a multilateral and participatory practice to build a brighter future for all (Teles, 2016).

\section{Conclusion}

Based on the framework of paradiplomacy, the Jember Regency has made its local identity in the form of art, culture, and other identities as part of its foreign relations ingredients. The Jember Regency can build partnership with several other countries in various fields of cooperation achieved through diplomacy, especially with Japan and Canada. This has been a positive action to promote the region's potentials, which in turn could also be a power and asset for improving the quality of the regional economy, human resources, and technological transfer. Furthermore, through this collaboration, the Jember Regency Government can train itself as a paradiplomacy actor, assisted by other stakeholders such as the University of Jember, which acts as the second track actor for city/regency diplomacy.

The author concludes that paradiplomacy activities through city/ regency diplomacy carried out by the Jember Regency Government use the conservative type. Because the pattern of foreign relations still expects facilitators, catalysts, and coordinators from the Ministry of Foreign Affairs in a one-door system. In addition, there has not been a significant amount of international cooperation carried out by the District Government, and 
there is no government representation in other countries. This means few collaborations as the DKI, West Java, East Java, and Yogyakarta Provinces. The formula pattern carried out by the Regency Governments also uses a coordinator join formula, parallel harmony so that the pattern of coordination and collaboration between the center and the regions is not competitive.

However, paradiplomacy, in this case, should mean that the Jember Regency Government can act as an actor and a place in city/regency diplomacy. The ability to perform as actors to conduct overseas cooperation with other countries and to provide places and networkings to create sister cities and smart cities is highly valuable. Nevertheless, the author still believes that there is still much to be done to maximize this opportunity, both from the support of human resources, institutions, technology, and financial fronts so that the Jember regency Government can be more optimal in playing its role at the international level in the future.

The author identifies that this paper still has weaknesses, and for future researchers, it should be able to develop this study more comprehensively. The weakness of this research is that it has not used primary data as a research database, and there is still little research on Jember that makes the overall research grounds less academic. Nonetheless, these regions have great potential to improve the quality of their governments to be more competitive at the national and regional levels. Subsequent authors should also identify other opportunities for international cooperation besides models of intergovernmental cooperation and educational pathways. This research is fundamental to be used to recommend local governments to become regions that can carry out maximum foreign relations.

\section{References}

Acuto, M. (2013). Global Cities, Governance. New York: Routledge.

Acuto, M., et.al. (2016). City Diplomacy and Twinning: Lessons from the UK, China and Globally. London: University College London.

Acuto, M. (2017). City Networks: New Frontiers for City Leaders. London: University College London.

Amiri, S., \& Sevin, E. (eds) (2020). City Diplomacy: Current Trends and Future Prospects. New York: Palgrave Macmillan.

Berita Ekspres. (2016). Pendidikan [Online]. 1 August. Available at: <https:// beritaekspres.com/2016/08/01/universitas-jember-2nd-internationalcultural-camp-ujicc/> [accessed 16 July 2021].

Bisnis. (2021). Realisasi Investasi Triwulan I 2021: Jabar Kuasai PMA dan PMDN [Online]. 26 April. Available at: <https://bandung.bisnis.com/ $\mathrm{read} / 20210426 / 550 / 1386382 /$ realisasi-investasi-triwulan-i-2021-jabarkuasai-pma-dan-pmdn> [accessed 15 July 2021].

BPS Kabupaten Jember. (2020). Produk Domestik Regional Bruto Kabupaten Jember Menurut Lapangan Usaha 2016-2020. Jember: BPS Kabupaten Jember. 
Carlnaes, W. (2013). Handbook Hubungan Internasional. Bandung: Nusamedia. Cummings, M.C. (2003). Cultural Diplomacy and the United States Government: A Survey.. Worthington, DC: Americans for the Arts.

Curtis, S. (2014). The Meaning of Global Cities: The Power of Cities in International Relations. Abingdon: Routledge.

Deganutti, C.D.(2017). Soft Power and Dark Heritage: Multiple Potentialities. International Journal of Cultural Policy, 23 (6), pp. 660-674.

Fathun, L.M. (2016). Paradiplomasi Menuju Kota Dunia: Studi Kasus Pemerintah Kota Makassar. Indonesian Perspective, 1 (1), pp. 75-94.

Fathun, L.M. (2018). Pariwisata di Era Ekonomi Digital: Sebuah Implementasi Pilar Kebijakan Poros Maritim di Era Jokowi dalam Konteks Paradiplomacy. Jurnal Dinamika Ekonomi Pembangunan, 1 (2), pp. 56-70.

Grandi, L.K. (2020). City Diplomacy. Basingstoke: Palgrave Macmillan.

Hone, J.K. (2021). The Emergence Digital Foreign Policy. Mlta: Diplo Foundation Anutruf.

IDP. (2021). Universitas Terbaik di Kanada tahun 2021 [Online]. Available at: <https://www.idp.com/indonesia/study-in-canada/top-universitiesin-canada/> [accessed 15 July 2021].

Kartajaya, H. (2005). Attracting Tourist Traders Investors: Strategi Memasarkan Daerah di Era Otonomi. Jakarta: Gramedia.

Klaus, I. (2018). Invited to the Party: International Organizations Evolve in an Urban World [Online]. The Chicago Council on Global Affairs. Tersedia di: <https://www. thechicagocouncil.org/sites/default/files/report_ international-organizations- in-urban-world_181028.pdf.> [accessed 17 September 2019].

Lord, C. (2000). Legitimacy, Democracy and the EU: When Abstract Questions Become Practical Policy Problems. Brighton: Sussex European Institute.

Mukti, T.A. (2020). Politik Paradiplomasi dan Isu Kedaulatan Indonesia. Yogyakarta: Phinisi Press.

Nye, J. (2004). Soft Power: The Means to Success in World Politics. New York: Public Affairs.

Pemkab Jember. (2019). Kerjasama Jember-Kanada [Online]. 17 September. Available at: $<$ https://www.jemberkab.go.id/jember-kanada-menjajakikerja-sama/> [accessed 9 July 2021].

Rayner, M.A. (2016). City Networks: Breaking Gridlocks or Forging (New) Lock-ins? International Affairs, 92 (5), pp. 1147-1166.

Rochman, M., Badjuri \& Luthfi, A. (2015). Analisis Potensi Pertumbuhan Ekonomi Kabupaten Jember Tahun 2010-2013. Artikel Ilmiah Mahasiswa 2015, 4.

Rosenau, J. (1971). Scientific Study of Foreign Policy. New York: Free Press. Sassen, S. (1991). The Global City. New Jersey: Princeton University Press. 
Sassen, S. (2017). Global Cities: Places for Researching the Translocal. In S. Hall \& R. Burdett (eds.), The SAGE Handbook of the 21st Century City, pp. 1143-1158. London: SAGE.

Soldatos, H.M. (1990). Federalism and International Relations: The Role of SubNational Units. New York: Oxford University Press.

Surabaya. (2021). Data Investasi Kota Surabaya [Online]. Available at: $<$ http:// dpm-ptsp.surabaya.go.id/v3/pages/data-investasi-kota-surabaya> [accessed 15 July 2021].

Tavares, R. (2016). Paradiplomacy Cities and States as Global Player. New York: Oxford University Press.

Teles, F. (2016). Local Governance and Inter-Municipal Cooperation. New York: Palgrave Macmillan.

Universitas Jember. (2020). Implementasi Kerjasama U2U [Online]. 7 August. Available at: <https://unej.ac.id/universitas-jember-dorongimplementasi-skema-kerjasama-u2u/> [accessed 16 July 2021].

Van der Pluijm, R. \& Mellisen, J. (2007). City Diplomacy: The Expanding Role of Cities in International Politics. The Hague: Netherlands Institute of International Relations Clingendael.

Wahyunik, S. (2019). Kerjasama Jember dan Jepang [Online]. 19 March. Available at: <https://surabaya.tribunnews.com/2019/03/19/pemkabjember-jajaki-kerjasama-dengan-konsulat-jepang> [accessed 9 July 2021]. 